\title{
Analysis of eutrophication trend of surface water in Tianjin coastal area
}

\author{
Shou Youping ${ }^{1}$, Zhao Junjie ${ }^{1, *}$ and Qiao Jianzhe ${ }^{1}$ \\ ${ }^{1}$ Laboratory of Waterway Environmental Protection Technology, Tianjin Research Institute for Water Transport Engineering, Tianjin \\ 300456, China
}

\begin{abstract}
In this study, the concentration of $\mathrm{COD}$, inorganic nitrogen (IN) and active phosphate $\left(\mathrm{PO}_{4}^{3-}\right)$ in surface water of Tianjin coastal area in the spring and autumn of 2008, 2010, 2013 and 2016 were collected. The results showed that the COD concentration had no obvious change while the concentration of IN and $\mathrm{PO}_{4}{ }^{3-}$ had a significant decline after land reclamation projects. As for seasonal changes, COD concentration is generally higher in autumn than in spring, while the concentration of $\mathrm{IN}$ and $\mathrm{PO}_{4}{ }^{3-}$ is generally higher in spring than in autumn. As for eutrophication index (E), it is generally higher in spring than autumn. In the spring of 2008 and 2010, the eutrophication index (E) bigger than 3 showed moderate eutrophication of surface waters. Since the reclamation began in 2010, the eutrophication index (E) of the coastal waters has decreased sharply, the level of eutrophication is mild during the construction period. With the construction of the port area, large-scale dredging and backfilling, the land-based pollutants have been effectively controlled, and the water quality of Tianjin coastal waters has been improved.
\end{abstract}

\section{INTRODUCTION}

With the rapid development of Marine economy and the deepening of coastal zone development, the discharge of a large number of industrial wastewater, domestic sewage and the use of pesticides and fertilizers have led to the continuous deterioration of the water quality in the coastal waters ${ }^{[1]}$. Eutrophication is a serious problem, red tide disasters occur frequently and the ecological environment is under great pressure ${ }^{[2]}$.

Bohai Bay, one of China's nine great bays, is located in the west of the Bohai Sea. It is a typical semi-closed bay with gentle slope, muddy and shallow water ${ }^{[3]}$. The landform basically slopes from south to north, from the near shore to the open sea, with an average depth of about 10 meters. Along the coast of Bohai Bay, several rivers have been injected, such as Jihe, Yongding Xinhe, Haihe, Duliujie and Ziya Xinhe. The water ecological environment is greatly affected by human activities. At the same time, the internal water flow in Bohai Bay is slow, and the exchange capacity with the external sea water is poor, and the pollutants entering the bay are not easy to transport and diffuse.

Tianjin's coastal waters receive up to 1 billion tons of sewage each year from Beijing, Tianjin and Hebei province $^{[4]}$. The semi-enclosed nature of Bohai Bay makes it difficult for pollutants discharged from land sources to rapidly diffuse to the outer sea area ${ }^{[5]}$. Coupled with the effect of waves and tidal currents, the coastal transport trend of pollutants is obvious ${ }^{[6]}$. It will

* Corresponding author: ppurelife@163.com cause a wider range of pollution in the tidal flat area and the coastal waters. Eutrophication is widely recognized as a major cause of Marine coastal environmental degradation which has aroused wide concern ${ }^{[7]}$.

The reclamation project of Nangang Industrial Zone began in June 2010 and completed in 2015. The peak period of reclamation was from 2011 to 2012. According to the temporal and spatial characteristics of reclamation in Tianjin Nangang Industrial Zone, four time nodes of 2008, 2010, 2013 and 2016 were selected in this study. The comparative study of monitoring data in spring and autumn is conducted to study the impact of reclamation on the offshore sea area near Nangang in Tianjin which is of great significance for controlling the pollution of the offshore sea area and improving the environmental quality.

\section{MATERIALS AND METHODS}

\subsection{Monitoring data}

This study we collected the monitoring data in March 2008 which monitored by Tianjin Aquatic Product Research Institute and the monitoring data in November 2008 which monitored by North Sea Environmental Monitoring Center of the State Oceanic Administration as the Marine water quality environment condition before the construction of Nangang Industrial zone. Collected the the monitoring data in May 2010, November 2010, April 2013 and October 2013 by North 
Sea Environmental Monitoring Center of the State Oceanic Administration as Marine water quality environment during the construction period of Nangang Industrial Zone. Collected the Marine water quality and environmental status after the completion of Nangang Industrial Zone in April and December 2016. The number of monitoring points in each year is shown in Table 1.

Marine water quality and environmental conditions of The Beihai Environmental Monitoring Center of the State Oceanic Administration during the construction period of Nangang Industrial Zone in May 2010, November 2010, April 2013 and October 2013.

Table 1. Monitoring points in each year.

\begin{tabular}{|c|c|c|}
\hline Time & $\begin{array}{c}\text { Relationship with } \\
\text { reclamation }\end{array}$ & $\begin{array}{c}\text { Number of water quality } \\
\text { monitoring stations }\end{array}$ \\
\hline 2008 & Before reclamation & 20 \\
\hline 2010 & During reclamation & $\begin{array}{c}20 \text { in } 2010.5 \\
44 \text { in } 2011.11\end{array}$ \\
\hline 2013 & During reclamation & 44 \\
\hline 2016 & After reclamation & 38 \\
\hline
\end{tabular}

\subsection{Research methods}

"Technical Regulations for Assessment of Seawater Quality Status (Trial)" (2015.10) introduced the method for calculation of eutrophication index $(\mathrm{E})$. The specific calculation formula is as follows:

$$
E=\left(C_{\mathrm{COD}} \times C_{\mathrm{DIN}} \times C_{\mathrm{DIP}} \times 10^{6}\right) / 4500
$$

$E-$ Eutrophication index.

$C_{\mathrm{COD}}$ the concentration of Chemical oxygen demand, $\mathrm{mg} / \mathrm{L}$.

$C_{\text {DIN }}$ the concentration of Inorganic nitrogen(IN$\mathrm{N})$, which is the sum of nitrite-nitrogen $\left(\mathrm{NO}_{2}-\mathrm{N}\right)$, nitratenitrogen $\left(\mathrm{NO}_{3}-\mathrm{N}\right)$ and ammonia-nitrogen $\left(\mathrm{NH}_{4}-\mathrm{N}\right), \mathrm{mg} / \mathrm{L}$. $\mathrm{mg} / \mathrm{L}$.

$C_{\text {DIP }}$ the concentration of Active phosphate,

Partition table of Eutrophication index are listed in Table 2 .

Table 2. Partition table of Eutrophication index (E).

\begin{tabular}{|c|c|}
\hline Eutrophication level & Eutrophication index(E) \\
\hline Light eutrophication & $1 \leq \mathrm{E} \leq 3$ \\
\hline Moderate eutrophication & $3<\mathrm{E} \leq 9$ \\
\hline Severe eutrophication & $1 \mathrm{E}>3$ \\
\hline
\end{tabular}

\section{RESULTS AND DISCUSSION}

\subsection{The concentration characteristics of COD}

In order to better analyze the evolution of seawater eutrophication before and after the construction of Tianjin Nangang Industrial Zone, the four monitoring data in spring and four monitoring data in autumn were compared and analyzed in this study. The monitoring data of COD concentration are listed in Table 3. It can be seen that the monitoring results of COD concentration in spring are between 1.28 and $1.72 \mathrm{mg} / \mathrm{L}$, and the monitoring results of COD concentration in autumn are between 1.55 and $1.86 \mathrm{mg} / \mathrm{L}$.

The interannual variation of COD concentration are showed in Figure 1. The annual variation of the monitoring results of COD concentration has no significant change. Generally, the COD concentration in the autumn is bigger than in the spring.

In general, before and after the reclamation, the COD content in the surveyed sea area did not change significantly. It can be seen that large-scale reclamation projects have no significant impact on COD content in the sea area.

Table 3. COD concentration monitoring results table.

\begin{tabular}{|c|c|c|c|c|}
\hline \multicolumn{2}{|c|}{ Survey Time } & \multicolumn{3}{c|}{ COD concentration $(\mathrm{mg} / \mathrm{L})$} \\
\cline { 3 - 5 } & $\begin{array}{c}\text { Minimum } \\
\text { value }\end{array}$ & $\begin{array}{c}\text { Maximum } \\
\text { value }\end{array}$ & $\begin{array}{c}\text { Mean } \\
\text { value }\end{array}$ \\
\hline \multirow{4}{*}{ Spring } & 2008.3 & $/$ & $/$ & 1.28 \\
\cline { 2 - 5 } & 2010.5 & 0.98 & 2.03 & 1.47 \\
\cline { 2 - 5 } & 2013.4 & 1.47 & 1.93 & 1.73 \\
\cline { 2 - 5 } & 2016.4 & 1.13 & 1.62 & 1.34 \\
\hline \multirow{5}{*}{ Autumn } & 2008.11 & 1.18 & 2.48 & 1.73 \\
\cline { 2 - 5 } & 2010.11 & 1.23 & 3.38 & 1.64 \\
\cline { 2 - 5 } & 2013.1 & 1.38 & 1.75 & 1.55 \\
\cline { 2 - 5 } & 2016.12 & 1.49 & 2.2 & 1.86 \\
\hline
\end{tabular}

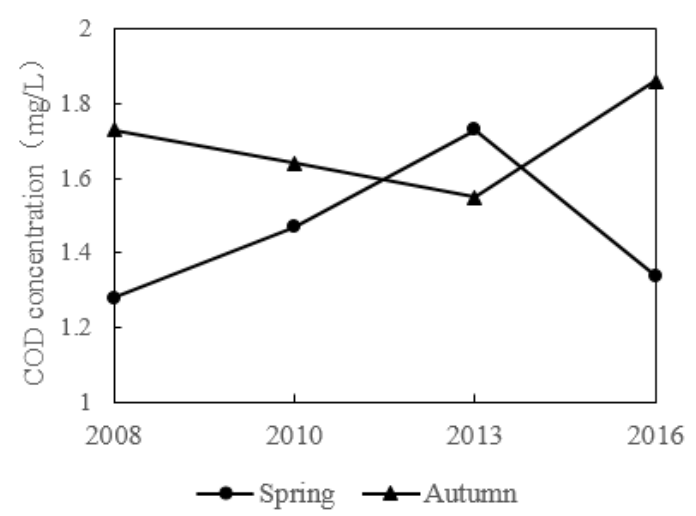

Figure 1. The interannual variation of COD concentration.

\subsection{The concentration characteristics of IN}

The monitoring data of inorganic nitrogen concentration are listed in Table 4. The interannual variation of inorganic nitrogen concentration are plotted in Figure 2. It can be seen that the monitoring results of inorganic nitrogen concentration in spring are between 0.33 and $0.65 \mathrm{mg} / \mathrm{L}$, and the monitoring results of inorganic nitrogen concentration in autumn are between 0.19 and $0.47 \mathrm{mg} / \mathrm{L}$. The interannual variation characteristics of inorganic nitrogen monitoring results showed a trend of first decreasing and then increasing. In the construction process of Nangang Industrial Zone, land-based pollutants have been effectively controlled, the concentration of inorganic nitrogen in surface water decreased significantly. 
Since the large-scale reclamation, the inorganic nitrogen content in the sea area has shown a trend of increase or decrease in some years, but after the reclamation, the change is not obvious compared with 2008, and its content is generally low, so it may be closely related to land-source pollution. According to the monitoring results of land-source pollutants discharged into the sea in the bulletin of the Marine environment of Tianjin over the years, the standard rate of land-source pollutants discharged into the sea is generally low, and the discharge characteristics of land-source pollutants appear high pollution to varying degrees, while inorganic nitrogen is usually one of the main pollution indexes of seawater near the sea-area of land-source pollutants discharged into the sea ${ }^{[8]}$. According to this analysis, inorganic nitrogen exceeding the standard in the sea area is mainly affected by land-based pollution.

Table 4. Inorganic nitrogen (IN) monitoring results table.

\begin{tabular}{|c|c|c|c|c|}
\hline \multirow{2}{*}{\multicolumn{2}{|c|}{ Survey Time }} & \multicolumn{3}{|c|}{ IN concentration $(\mathrm{mg} / \mathrm{L})$} \\
\hline & & \multirow{2}{*}{$\frac{\begin{array}{c}\text { Minimum } \\
\text { value }\end{array}}{1}$} & \multirow{2}{*}{$\begin{array}{c}\begin{array}{c}\text { Maximum } \\
\text { value }\end{array} \\
\text { / }\end{array}$} & \multirow{2}{*}{$\begin{array}{l}\text { Mean } \\
\text { value }\end{array}$} \\
\hline \multirow{4}{*}{ Spring } & 2008.3 & & & \\
\hline & 2010.5 & 0.41 & 0.81 & 0.65 \\
\hline & 2013.4 & 0.24 & 0.57 & 0.40 \\
\hline & 2016.4 & 0.21 & 0.46 & 0.33 \\
\hline \multirow{4}{*}{ Autumn } & 2008.11 & 0.27 & 0.57 & 0.47 \\
\hline & 2010.11 & 0.17 & 0.48 & 0.25 \\
\hline & 2013.1 & 0.06 & 0.49 & 0.19 \\
\hline & 2016.12 & 0.16 & 0.50 & 0.32 \\
\hline
\end{tabular}

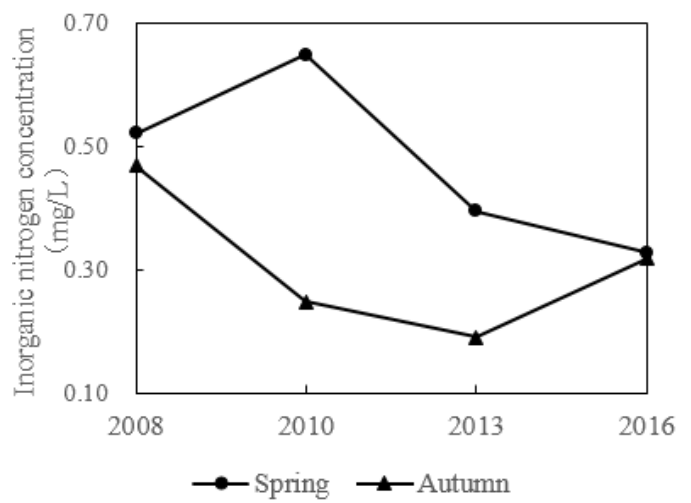

Figure 2. The interannual variation of inorganic nitrogen concentration.

\subsection{The concentration characteristics of active phosphate $\left(\mathrm{PO}_{4}{ }^{3-}\right)$}

The monitoring data of active phosphate $\left(\mathrm{PO}_{4}{ }^{3-}\right)$ concentration are listed in Table 5. The interannual variation of active phosphate concentration are plotted in Figure 3. It can be seen that the monitoring results of active phosphate concentration in spring are between 2.22 and $29.06 \mu \mathrm{g} / \mathrm{L}$, and the monitoring results of active phosphate concentration in autumn are between 6.7 and $19.1 \mu \mathrm{g} / \mathrm{L}$. The interannual variation characteristics of the monitoring results of active phosphate showed a downward trend. In the construction process of Nangang Industrial zone, as the terrestrial pollutants were effectively controlled.

The concentration of active phosphate is decreasing, which indicates that the control of phosphorous input from land source has been effective in recent years.

Table 5. Active phosphate $\left(\mathrm{PO}_{4}{ }^{3-}\right)$ monitoring results table.

\begin{tabular}{|c|c|c|c|c|}
\hline \multicolumn{2}{|c|}{ Survey Time } & \multicolumn{3}{|c|}{ Phosphate( $\begin{array}{c}\left.\mathrm{PO}_{4}{ }^{3-}\right) \text { concentration } \\
(\mu \mathrm{g} / \mathrm{L})\end{array}$} \\
\cline { 2 - 5 } & $\begin{array}{c}\text { Minimum } \\
\text { value }\end{array}$ & $\begin{array}{c}\text { Maximum } \\
\text { value }\end{array}$ & $\begin{array}{c}\text { Mean } \\
\text { value }\end{array}$ \\
\hline \multirow{5}{*}{ Spring } & 2008.3 & $/$ & $/$ & 29 \\
\cline { 2 - 5 } & 2010.5 & 10.4 & 55.9 & 29.06 \\
\cline { 2 - 5 } & 2013.4 & 2.01 & 20.4 & 11 \\
\cline { 2 - 5 } & 2016.4 & 1.96 & 2.55 & 2.22 \\
\hline \multirow{5}{*}{ Autumn } & 2008.11 & 7.27 & 35.9 & 19.1 \\
\cline { 2 - 5 } & 2010.11 & 1.59 & 19.6 & 6.7 \\
\cline { 2 - 5 } & 2013.1 & 2.8 & 33.9 & 7.93 \\
\cline { 2 - 5 } & 2016.12 & 2.5 & 22.7 & 10 \\
\hline
\end{tabular}

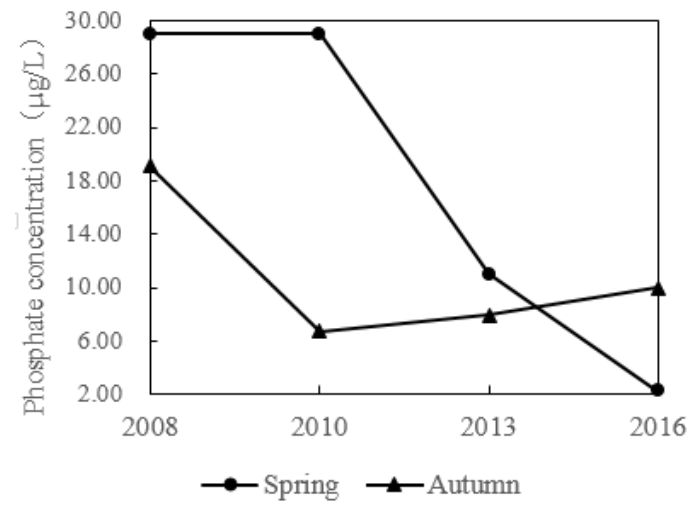

Figure 3. The interannual variation of active phosphate $\left(\mathrm{PO}_{4}{ }^{3-}\right)$ concentration.

\subsection{The concentration characteristics of eutrophication index(E)}

The interannual variation of eutrophication index (E) are plotted in Figure 4. The results showed that the eutrophication index (E) in spring and autumn of 2008 was 4.30 and 3.44 , respectively. The eutrophication index (E) in the spring and autumn of 2013 was 1.67 and 0.52 , respectively. The eutrophication index (E) in spring and autumn of 2016 was 0.22 and 1.32 , respectively.

Generally speaking, eutrophication index (E) in the spring is greater than in the autumn. Eutrophication index (E) $>3$ in 2008 and in the spring of 2010 showed that the coastal waters of Tianjin id moderate eutrophication. However, since construction began in 2010, the eutrophication index (E) of the nearshore sea area decreased sharply, and the level of eutrophication was mild during construction.

In general, the eutrophication index $(\mathrm{E})$ is greater in spring than in autumn. Meanwhile, with the development 
and construction of Nangang Industrial Zone, the eutrophication index of water body generally presents a downward trend. Especially in 2010, the decrease of eutrophication index (E) was particularly obvious, which was mainly caused by the significant decrease of phosphate and inorganic nitrogen.

The change of Eutrophication index (E) was mainly caused by the concentration change of inorganic nitrogen and active phosphate. Studies have shown the the coastal waters of Tianjin are mainly polluted by nitrogen and phosphorus, and the organic pollution is relatively light, and the eutrophication situation is severe ${ }^{[9]}$. This is consistent to the research results of this paper.

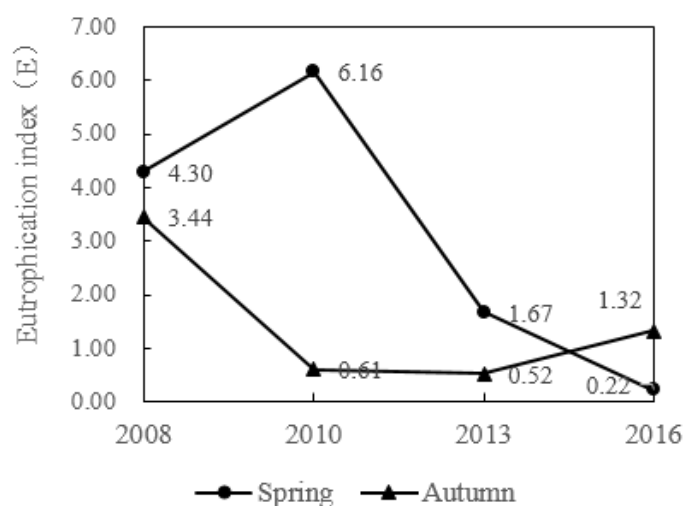

Figure 4. The interannual variation of eutrophication index(E).

\section{CONCLUSION}

As for the seasonal variation characteristics of eutrophin, COD concentration is generally higher in autumn than in spring, while the concentration of inorganic nitrogen and active phosphate is generally higher in spring than in autumn.

For the characteristics of annual change, the annual change of COD concentration is not obvious, and the reclamation project has little impact on COD concentration. For inorganic nitrogen and active phosphate, the trend of decrease followed by increase was generally presented.

Generally speaking, eutrophication index (E) in the spring is greater than in the autumn. Eutrophication index (E) $>3$ in 2008 and in the spring of 2010 showed that the coastal waters of Tianjin is moderate eutrophication. However, since construction began in 2010, the eutrophication index (E) of the nearshore sea area decreased sharply, and the level of eutrophication was mild during construction.

The coastal waters of Tianjin are mainly polluted by nitrogen and phosphorus. Pollutants are mainly imported from land sources.

\section{ACKNOWLEDGMENTS}

This paper is one of the phased achievements of the National Nonprofit Institute Research Grants of Tianjin Research Institute for Study on integrated Remediation technology of Immobilized microorganisms in Polluted sea water (No. TKS190408).

\section{REFERENCES}

1. Shahidul I.M., Masaru T. (2004) Impacts of pollution on coastal and marine ecosystems including coastal and marine fisheries and approach for management: a review and synthesis. Marine Pollution Bulletin, 48(7): 624-649.

2. Hallegraeff G. M. (1993) A review of harmful algal blooms and their apparent global increase. Phycologia, 32(2): 79-99

3. $\mathrm{Mu}$ D. (2012)Effect of nutrients on planktonic ecological dynamics in Bohai Bay. Journal of Tianjin University, 42-47.

4. Nie H.T., Tao J.H.(2008) Impact of coastal exploitation on the eco-environment of Bohai Bay, THE OCEAN ENGINEERING,26(3):44-50.

5. Sun T., Tao J.H.(2005). Experimental and numerical study of wave-induced long-shore currents on a mild slope beach. China Ocean Engineering, 19(3): 469484.

6. Stelling G.S., Wiersma A.K., Willemse J.B.T.M. (1986) Practical aspects of accurate tidal computations. Journal of Hydrodynamic Engineering, 112:802-817.

7. Duarte C.M. (2009) Coastal eutrophication research: A new awareness. Hydrobiologia, 629:263 -269.

8. Nikolaidis G., Patoucheas D.P., Moschandreou K. (2006) Estimating breakpoints of Chl-a in relation with nutrients from Thermaikos gulf (Greece) using piecewise linear regression. Fresenius Environmental Bulletin, 15(9B): 1189-1201.

9. Xu X.F. (2012) Study on Characteristics of Aquatic Ecological Environment of Tianjin Coastal Water and Its Spatial Decision Support System. Journal of Tianjin University, 26-27. 